\title{
EREMICI I PUSTELNICY W POLSCE ŚREDNIOWIECZNEJ. WYBRANE ZAGADNIENIA
}

W dziejach monastycyzmu polskiego $\mathrm{w}$ średniowieczu eremici i pustelnicy odegrali ważną rolę ${ }^{1}$. Pierwszymi znanymi z imion eremitami w Polsce byli mnisi tworzący tzw. Erem Pięciu Braci. Żywot Pięciu Braci Męczenników napisany przez Brunona $z$ Kwerfurtu jest najstarszym źródłem ukazującym eremitów w Polsce ${ }^{2}$. Pozwala na ukazanie osób, które przyczyniły się do założenia eremu, okoliczności jego powstania i składu personalnego. Pierwsi polscy eremici Benedykt i Jan pochodzili z klasztoru w Pereum koło Rawenny. Najwiekszą sławę zyskał pustelnik Benedykt, którego grota znajdowała się na górze Sorakte. Benedykt okazał się jednym $z$ najwybitniejszych uczniów św. Romualda. Został przez niego wybrany, aby udać się do dalekiego kraju w celu założenia tam eremu. Św. Romuald realizowal w ten sposób wolę cesarza Ottona III, który chciał „braci z pustelni, którzy byli pełni zapału, wysłać do kraju Słowian (...)". Od cesarza Benedykt otrzymał księgi liturgiczne i ornat. Tekst Żywota wspomina także, że na ołtarzu w kościele eremu Pięciu Braci w Polsce znajdowały się jakieś relikwie. Nie można wykluczyć, że relikwiarz ofiarował eremitom również cesarz Otto III. Nie ma danych umożliwiających identyfikację tych relikwii, a tym samym nie możemy się też wypowiedzieć o wezwaniu kościoła eremitów. Erem powstał dzięki Bolesławowi Chrobremu. Przyjął on Benedykta i Jana ,z niezwykłą uprzejmością i z wielkim upragnieniem. I we wszystkim okazując im laskawość, w zacisznej pustelni z wielka gotowością zabudował miejsce, które sami upatrzyli jako odpowiednie dla ich życia, i dostarczał im środków niezbędnych do istnienia bez trudu". Z Żywota Pięciu Braci nie dowiemy się też, niestety, o lokalizacji eremu. Bruno posłużył się bowiem ogólnym określeniem, że miejsce, w którym powstał erem znajdowało się tam, ,gdzie piękny las nadawałby się na samotnię". Z tego określenia można wywnioskować tylko, że zamierzano zachować pustelniczy cha-

${ }^{1}$ Por. najnowsze opracowanie M. K a n i o r a OSB, Historia monastycyzmu chrześcijańskiego, t. 2, Kraków 2002, s. 405 n.

${ }^{2}$ Wszystkie cytaty z Żywota Pięciu Braci pochodzą z wydawnictwa Brunon z Kwerfurtu, Żywot Pięciu Braci Męczenników, tłum. K. Abgarowicz, oprac. J. Karwasińska, Warszawa 1966, [w:] Piśmiennictwo czasów Boleslawa Chrobrego, Warszawa 1966 
rakter fundacji nowej placówki klasztornej. Wiele razy w źródle klasztor nazywany jest pustelniq, w której przebywają Benedykt i Jan oraz Polacy, Mateusz i Izaak. Ostatnio A. M. Wyrwa, który dokonał najpełniejszego przeglądu literatury, stwierdza, że mnisi przybyli z klasztoru Pereum koło Rawenny, którego przełożonym byl św. Romuald. W okresie, kiedy Benedykt i Jan zostają wysłani do Polski w klasztorze Pereum panowała obostrzona regula św. Benedykta. Eremitów tych, z samego początku XI w. nie można nazywać kamedułami, gdyż wspólnotę w Camaldoli św. Romuald założył w 1012 roku $^{3}$. Dodajmy, że Benedykt, wedle Bruna, miał przez całe życie posługiwać się reguła, ,którą otrzymał od swego nauczyciela Romualda”. Wszystkie polskie źródła konsekwentnie zwą Pięciu Braci eremitami.

Niewątpliwie erem powstał $z$ dala od najważniejszych centrów państwa Bolesława Chrobrego, przy czym należy dodać, że w jakiejś adległości od eremu znajdowała się nieznana bliżej wieś, do której w przeddzień ich męczeństwa został posłany sługa klasztorny. Więcej mówiący jest ten fragment Żywota, w którym czytamy, że erem znajdował się „na ziemi chrześcijańskiej, w pobliżu pogan". Można także dodać, że skoro, zdaniem autora Żywotu, pogrzebu Pięciu Braci dokonał biskup Unger, to erem mógł znajdować się na terenie diecezji poznańskiej. Wzmiankę o nazwie miejscowości, w której w 1005 r. znajdował się opustoszały klasztor podal Thietmar z swej kronice. Jego zdaniem w wrześniu 1005 wojska króla Henryka II dotarły do opactwa zwanego Mezerici. Mnichów w nim nie było, ale istniały budynki klasztorne i kościół. Dzięki temu król mógł zarządzić, aby w tym miejscu uczcić święto męczenników Legii Tebańskiej, ,starając się, aby ani klasztor, ani mieszkania nieobecnych mnichów nie ponosiły żadnej szkody z ich strony"4. Dla kwestii lokalizacji eremu bardzo ważna jest wzmianka z rocznika kamienieckiego, który wymienił nazwę Kazimierz jako miejsce męczeńskiej śmierci (Anno 1003 heremite in Polonia martirizati sunt in Kazimir) ${ }^{5}$. Rocznik Sędziwoja lokalizował ich śmierć in quodam opido prope Konyn ${ }^{6}$.

W toku wieloletniej dyskusji zarysowały się aż cztery propozycje lokalizacji eremu Pięciu Braci. Ograniczając się do stosunkowo nowej literatury stwierdzić należy, że T. Dusza opowiedział się za Kazimierzem Biskupim jako siedzibą ere$\mathrm{mu}^{7}$. Badania nad sakralną przeszłością Kazimierza Biskupiego są dość zaawansowane $^{8}$. K. Górska-Gołaska odrzuca hipotezę o istnieniu eremitów w Kazimierzu

${ }^{3}$ A. M. W y rwa, Sredniowieczna sieć klasztorów w Wielkopolsce i na Kujawach. Stan, potrzeby badań $i$ wstępna analiza problemu, [w:] Zakony $i$ klasztory w Europie Środkowo-Wschodniej X-XX wiek, red. H. Gapski, J. Kłoczowski, Lublin 1999, s. 76-146.

${ }^{4}$ Kronika Thietmara, tłum. M. Z. Jedlicki, Poznań 1953, s. 353.

${ }^{5} \mathrm{MPH}$ HI, s. 777.

${ }^{6} \mathrm{MPH}$ II, s. 873.

${ }^{7}$ T. D u s z a, Kazimierz Biskupi pierwszq i jedynq siedziba Pięciu Braci, „Kronika Diecezji Włocławskiej" 67(1984), s. 275-285; por. tegoż, Pięciu Braci-kwestie kontrowersyjne, NP 68,1986 , s. 5-59.

${ }^{8}$ J. D u b i jakt i s, Sprawozdanie z badań archeologicznych przeprowadzonych przy kościele sw. Marcina w Kazimierzu Biskupim w latach 1985-1986, „Acta Universitatis Nicolai Copernici. Seria Archeologia" 17, 1991, s. 61-69; K. Gorczyca, Czasy najdawniejsze, [w:] Dzieje Kazimierza Biskupiego, cz. 1: Monografia, red. Z. Chodyła, Kazimierz Biskupi-Poznań 
Biskupim. Ośrodek ten, jej zdaniem, odegrał ważna rolę jako miejsce kultu Pięciu Braci, ale dopiero, kiedy biskup Jan Lubrański na początku XVI w. ufundował w Kazimierzu Biskupim klasztor bernardynów ${ }^{9}$. Z kolei G. Labuda, który uważa zapiskę rocznika kamienieckiego za przejętą wiernie z zaginionego rocznika dawnego, skierował uwagę badaczy na Kazimierz koło Szamotul ${ }^{10}$. Jeszcze inni zaproponowali Trzemeszno ${ }^{11}$. Od czasów badań $T$. Wojciechowskiego mocną pozycję zajmował pogląd upatrujący lokalizacji eremu Pięciu Braci w lubuskim Międzyrzeczu $^{12}$. Także ostatnio, po rozpatrzeniu różnych poglądów, A. M. Wyrwa przyjmuje istnienie najstarszego klasztoru eremitów w Międzyrzeczu. Podziela sceptycyzm, co do istnienia klasztoru w Kazimierzu Biskupim. Stwierdza również, że na obecnym etapie badań nie można udowodnić istnienia takiego klasztoru w Kazimierzu koło Szamotuł ${ }^{13}$. Także A. Pleszczyński wykazuje, że klasztor w Międzyrzeczu istnial w czasach Thietmara ${ }^{14}$.

Usytuowanie eremu „w pobliżu pogan" oznacza, że od samego początku eremici mieli oddziaływać misyjnie na pogańskich sąsiadów państwa Bolesława Chrobrego, niewatpliwie na Pomorzan. O Benedykcie źródło przekazało frapująca wiadomość, że znał on język słowiański. Nie wiemy jednak, czy nauczył się go przed wyruszeniem do Polski, czy też nabył tę umiejętność dopiero w eremie. Zastanawiające bardzo jest także i to, że Benedykt dokonał kamuflażu w celu pozbawienia się zewnętrznych oznak mnichostwa. Żywot podał, że miał on tonsurę, a aby ją ukryć, po prostu ogolił całą głowę. Zdjął habit mnicha i odział się w strój świecki. Eremita z nieznanych nam powodów przewidywał, jak można się z tego domyślać, że jako mnich nie zostanie przez pogan dobrze przyjęty. Żywot stwier$\mathrm{dza}$, że eremici nie odnieśli żadnych sukcesów misyjnych. Erem, składający się początkowo z dwu mnichów, Benedykta i Jana, powiększył się w Polsce o braci Mateusza i Izaaka. Warto dodać, że nieznane z imienia siostry Mateusza i Izaaka znalazły się w pobliżu eremu i ,służyły Bogu w klasztorze w gronie dziewic", co można interpretować jako dowód istnienia obok niewielkiego klasztoru żeńskiego. Dobrze znana jest także inna, zupełnie nie eremicka, strona ich działalności, a mianowicie udział w politycznych planach księcia Bolesława Chrobrego. Książę

1993; A. M ill e r, J. Ro d z i ew i c z, M. K oł y s z k o, Konserwacja elewacji kościota pw. św. Marcina w Kazimierzu Biskupim, „Biuletyn Informacyjny Konserwatorów Dzieł Sztuki”, nr 1, 2000.

${ }^{9}$ K. G ó r s k a - G oł a s k a, Kazimierz Biskupi w średniowieczu, [w:] Dzieje Kazimierza Biskupiego, cz. 1: Monografia, red. Z. Chodyła, Kazimierz Biskupi-Poznań 1993, s. 33-48

${ }^{10} \mathrm{G}$. L a bud a, Szkice historyczne jedenastego wieku, I: Najstarsze klasztory $w$ Polsce, „Archeologia Historica Polona” 2(1995), s. 7-73; por. tegoż, Rocznik poznański, „Studia Żródłoznawcze", 2(1958), s. 104.

$"$ A. Nadolski, A. A bramowicz, T. Poklewski, A. Kąsinow ski, Łęczyckie opactwo Panny Marii w świetle badań z lat 1954-56, Łódź 1960, s. 76-81.

${ }^{12}$ T. Wo j c i e c h ow s k i, Szkice historyczne XI wieku, Warszawa ${ }^{3} 1951$, s. $31-85$.

${ }^{13}$ A. M. W yrwa, op. cit.

${ }^{14}$ A. P l e s z c z y ń s k i, Bolestaw Chrobry konfratrem eremitów św. Romualda w Międzyrzeczu, KH 103(1996), zesz. 1, s. 3-22; o roli Międzyrzecza zob. S. Kurnatowski, J. N a le p a, Z przeszlości Międzyrzecza, Poznań 1961; T. J u r e k, Kościoly średniowiecznego Międzyrzecza, [w:] Kraje stowianskie w wiekach średnich, red. H. Koćka-Krenz, W. Losiński, Poznań 1998, s. 613-621. 
wysłał Benedykta $z$ misja, wyposażywszy go w 10 funtów srebra. Eremita dotarł tylko do Czech, a ponieważ była wówczas wielka zawierucha wojenna, nie mógł jechać dalej i powrócił do eremu niczego nie wskórawszy $y^{15}$.

Podczas napadu na erem w nocy z 10 na 11 listopada 1003 r. śmierć ponieśli kolejno Jan, Benedykt, Izaak i Mateusz. Zginał również ich kucharz Krystyn, jedyny, który usiłował się bronić. Relację o napadzie autor Żywota napisał na podstawie opowieści przywódcy napastników. Benedykta, Jana, Izaaka i Mateusza pochowano we wspólnym grobie, natomiast Krystyn został pochowany osobno. Erem odrodził się ok. 1012, jeszcze w czasach Bolesława Chrobrego. W Żywocie zachowały się imiona kolejnych eremitów, których dziełem było zapoczattkowanie kultu męczenników. Do ich grona został dokooptowany kucharz Krystyn, gdyż przekonano się po otwarciu jego grobu, że zasługuje on na spoczywanie wraz $z$ eremitami.

Rozwój kultu Pięciu Braci Męczenników znamy, niestety, tylko w ogólnym zarysie. Jest to zagadnienie bardzo ważne, gdyż poprzez kult świętych eremitów propagowano ideały życia eremickiego. Pierwszym ośrodkiem kultu był grób męczenników w kościele znajdującym się na terenie eremu. Żywot wzmiankuje cudowne światła rozbłyskujace nad grobem oraz inne typowe elementy hagiograficzne $^{16}$.

Zastanawiające są najwcześniejsze losy relikwii Pięciu Braci. Początkowo znajdowały się $\mathrm{w}$ ich eremie, który dzięki temu mógł wyrosnąć na ważne, obok Gniezna, miejsce pielgrzymkowe. Ciała pomordowanych Pięciu Braci pochowano w kościele klasztornym, o czym informuje Bruno i nie ma podstaw, aby mu nie wierzyć. Pogrzeb odbył się wkrótce po ich męczeńskiej śmierci. Bruno z Kwerfurtu ubolewał, że z powodu nieszczęsnej wojny z Henrykiem II polski książę Bolesław Chrobry nie może otoczyć należytym kultem Pięciu Braci Męczenników. Kryje się tutaj sugestia, że relikwie te spoczywały w zapomnieniu ${ }^{17}$. Od ok. 1012 r. erem wznowił działalność. Bruno odnotował cudowne zjawiska w postaci ukazywania się św. Benedykta i św. Jana, którzy wstawiali się za swoimi zabójcami. Przełożonym w eremie był wówczas Antoni, wielokrotnie opisywany w naszej literaturze.

Wiadomo z kroniki Kosmasa, że podczas najazdu księcia Brzetysława relikwie Pięciu Braci znajdowały się w Gnieźnie, w kościele katedralnym. Jeżeli przyjmujemy, ze Kosmas jest prawdomówny w kwestii istnienia tam relikwii Pięciu Braci, to nasuwa się pytanie, kto i kiedy przeniósł relikwie z eremu do Gniezna. Przypuszcza się, że kres funkcjonowania eremu przyniosła tzw. reakcja pogańska w latach trzydziestych XI w. Wówczas relikwie mogły zostać przeniesione

${ }^{15}$ Por. T. Woj c i e ch ow s k i, Szkice historyczne, s. 42-43.

${ }^{16}$ T. D u s z a, Dzieje kultu św. Pięciu Braci Pustelników: Benedykta, Jana, Mateusza, Izaaka, Krystyna, „Kronika Diecezji Włoclawskiej” 50(1967), s. 110-116; K. G ó r s k a - G oł a sk a, Kult Pięciu Braci Męczenników w Kazimierzu Biskupim i rozwój towarzyszqcej mu legendy, RH 61(1995), s. 111-140; Pięciu Braci Męczenników. Z dziejów religijności Polski XI w., red. D. Zydorek, Gorzów Wielkopolski 1997.

${ }^{17}$ J. K a r wa s ińs k a, Świadek czasów Chrobrego - Brunon z Kwerfurtu, [w:] Polska w świecie. Szkice z dziejów kultury polskiej, Warszawa 1972, s. 103. 
do kościoła metropolitalnego w Gnieźnie, co nie uchroniło ich przed świętokradztwem dokonanym przez Czechów, którzy wywieźli wspomniane relikwie. Osobnego referatu wymagałaby kwestia losów kultu Pięciu Braci w Czechach średniowiecznych. O przejawach ich kultu w Polsce warto wspomnieć, że w tzw. kalendarzu księżnej Gertrudy z 2 poł. XI w. święto męczeństwa Pięciu Braci wpisano pod mylną datą 10 XI. Święto to nie znikło $z$ kalendarzy liturgicznych w Polsce także w XII i XIII w. Nie są mi też znane średniowieczne fundacje kościołów w Polsce pod wezwaniem Pięciu Braci. W katedrze krakowskiej przed 1513 powstał ołtarz im dedykowany ${ }^{18}$. Ottarz pod tym wezwaniem powstał także w katedrze poznańskiej z fundacji Lubrańskich w 1522. Lubrańscy i król Zygmunt I podjęli starania o uzyskanie $\mathrm{z}$ Czech relikwii. Ich efektem bylo sprowadzenie relikwii Pięciu Braci, które 11 XI 1536 umieszczono w kościele w Kazimierzu Biskupim. Stał się on głównym ośrodkiem ich kultu, propagowanym przez opiekujących się tym kościołem bernardynów ${ }^{19}$.

Erem Pięciu Braci powstał w kręgu oddziaływania duchowości św. Romualda. Były też zapewne w Polsce XI w. inne, aczkolwiek słabo rozpoznane, źródła tradycji eremickich. Przypomnieć tu należy, że do starych odkryć archeologicznych w Krakowie należy grota $\mathrm{z}$ wykutymi w skale stopniami, przytulona do stoku Góry św. Benedykta (od XIV w. zwanej Górą Lasoty). Na górze tej istniał od 1 połowy XI w. kościółek św. Benedykta, zaś wspomniana grota może być śladem równie starej pustelni ${ }^{20}$.

Doliną Dunajca wędrował w XI w. pustelnik św. Andrzej Świerad. Wiele już napisano o wspaniałej postaci tego świętego, który pochodził przecież z ziemi polskiej, ale pamięć o nim funkcjonuje jakby w cieniu św. Wojciecha ${ }^{21}$. On to ,znalazł się na pustelniczym odludziu, nieustannie praktykował posty, które wprawdzie bardzo wyniszczały ciało, ale wzmacniały jego życie duchowe"22.

Z źródłowych przekazów najcenniejszy jest $\dot{Z} y w o t$ św. Andrzeja Swierada, którego autorem był Maur, biskup Pecs na Węgrzech. Dzieło powstało przed 1070. Spośród barwnych opisów działalności Świętego warto najpierw przyjrzeć się wzmiankom o jego praktykach ascetycznych. Były one niezwykle surowe, począwszy od ścisłego postu praktykowanego w poniedziałki, środy i piątki, po sposób, w jaki w nocy wypoczywał oraz lańcuchy, które opasywały jego ciało. Sw. Andrzej zasiadał na noc na pieńku drzewa, a przeznaczeniem wbitych wokół niego naostrzonych palików i kamieni zawieszonych na głowie było, aby święty nie mógł zasnąć. Pod habitem nosił ciężki łańcuch, opasujący jego ciało. Odkryto go

${ }^{18}$ J. R a j m a n, Średniowieczne patrocinia krakowskie, Kraków 2002, s. 38.

19 J. M i t k ow sk i, Pięciu Braci Polskich, [w:] Hagiografia polska, t. 2, pod red. R. Gustawa, Poznań s. 246; por. Pięciu Braci Męczenników. Z dziejów religijności Polski XI wieku, dz. cyt.; ostatnio B. K ü r b i s, Bruno z Kwerfurtu i poczq̨tki kultu Pięciu Braci, [w:] Polska na przelomie I i II tysiaclecia, pod red. S. Skibińskiego, Poznań 2001.

${ }^{20} \mathrm{~J}$. R a j ma n, Mons ante Cracoviam. Najdawniejsze dzieje kościola św. Benedykta na Górze Lasoty, „Rocznik Krakowski”, t. 60(1994), s. 5-20.

${ }^{21}$ Por. ostatnio zbiór studiów Święty Świerad i jego czasy. Materiaty z Sympozjum Naukowego w Tropiu 10-1/ lipca 1998, pod red. S. Pietrzaka, Nowy Sącz 2001.

22 Zywot świętych pustelników Zoerada Wyznawcy i Benedykta Męczennika napisany przez biskupa Pécsu Maurusa, w: Swięty Swierad i jego czasy, s. 299-305. 
dopiero po śmierci św. Andrzeja i wydaje się, że łańcuch ten był przyczyną powstania zakażenia, które doprowadziło do zgonu: ,gdy czcigodne ciało leżało już martwe, rozebrawszy je do obmycia, zauważył łańcuch mosiężny wżerający się do wnętrzności. I oto dziwna i niesłychana rzecz: lańcuch niszczący gangreną ciało wewnątrz, na zewnątrz porosły był skórą. Lecz nikt by się tego rodzaju męczeństwa nie mógł domyśleć, gdyby na brzuchu nie zauważono metalowej sprzączki. Gdy juź rozpięty łańcuch wyciągano $z$ ciała, dał się słyszeć nieprzyjemny chrzęst uszkadzanych żeber".

Powstrzymywanie się od snu i spętanie ciała łańcuchem to praktyki wskazujące wyraźnie na ascetyzm wschodni, a nie benedyktyński. Zbliżało to św. Andrzeja to ascetów zwanych akoitmetoi oraz siderophoroi, odnotowywanych w monastycyźmie bizantyjskim. Postępował ,wzorując się na regule zakonnej, która kierował się opat Zozimas"23. Zapoznał się z nimi zapewne w opactwie św. Hipolita na górze Zobor koło Nitry.

Św. Andrzej Świerad ciężko pracował przy wyrębie lasu, równocześnie pościł do tego stopnia, że raz nawet zasłabł przy pracy. W okresie Wielkiego Postu, który trwał u niego 8 tygodni, pożywienie ograniczał do jednego orzecha dziennie. Pierwszym ośrodkiem kultu św. Andrzeja Świerada była Nitra. Tam miały się za jego pośrednictwem dokonywać cuda w postaci wskrzeszenia zmarłego oraz uratowania od śmierci powieszonego. Kanonizacja nastapiła w 1083, a na początku XII w. pojawiło się jego wezwanie przy dedykacji kościoła zamkowego w Nitrze.

W Polsce pierwsze patrocinium św. Andrzeja Świerada związane jest z kościołem parafialnym w Tropiu nad Dunajcem. Badania archeologiczne wykazaly, że najstarszy kościół w Tropiu mógł powstać już drugiej połowie w XI w. Wezwanie kościoła przypuszczalnie dało nazwę całej miejscowości. W 1307 zapisano po raz pierwszy, że wieś nazywa się Święty Świerad, a w licznych dalszych zapiskach powtarzano tę nazwę, czasami dodając, że wieś ta nazywa się także Tropie. Miejsce owiane było chyba już w średniowieczu różnymi legendami. Jan Długosz udokumentował istnienie pustelni św. Andrzeja Świerada w Tropiu. Zamieszkiwać ją miał jeszcze przed wyruszeniem do $\mathrm{Nitry}^{24}$.

Prawdopodobnie z XII w. pochodzi kościół w Oławie na Śląsku, który zdaniem niektórych badaczy, mógł nosić również wezwanie św. Andrzeja Świerada. W dokumencie biskupa wrocławskiego Rudolfa z 1468 można przeczytać, że św. Andrzej Świerad przebywał niegdyś w Oławie ${ }^{25}$.

${ }^{23}$ Literatura na ten temat jest olbrzymia, por. przykładowo H. D e l a h a y e, Życie monastyczne w Bizancjum, [w:] Bizancjum. Wstep do cywilizacji wschodniorzymskiej, oprac. N. H. Baynes i H. St. L. B. Moss, Warszawa 1964 oraz R. Morri s, Monks and Laymen in Byzantium, 843-1118, Cambridge 1995.

${ }^{24} \mathrm{~S}$. P i e trzak, Kosiciól w Tropiu jako naddunajecki ślad św. Swierada, [w:] Swięty Síwierad, s. 280-290.

${ }^{25}$ Zob. w starszej literaturze ważne wciąż uwagi T. S i 1 n i c k i e g o, Dzieje i ustrój Kościola katolickiego na Śląsku do końca XIV w. Warszawa 1953, s. 94, gdzie również na temat domniemanych tradycji eremickich we wrocławskim opactwie św. Marcina. Ostatnio kult w Oławie omówił J. Swastek, Święty Andrzej Świerad i jego kult w średniowiecznej Oławie do 1534 roku, w: Święty Świerad, s. 265-279. 
Nie ustosunkowując się do tradycji śląskiej, wskażę, że oprócz św. Andrzeja Świerada można domniemywać o działalności w ziemi sądeckiej jeszcze kilku innych eremitów. Pierwszym z nich był jego uczeń św. Benedykt, aczkolwiek dopiero Legenda św. Stefana oraz zależny od niej przekaz Długosza zawierają wiadomość, że Benedykt wywodził się z ziemi polskiej. Nie można wykluczyć, że te późniejsze od Żywotu źródła rozszerzyły na Benedykta wiadomość dotycząca pochodzenia św. Andrzeja Świerada. Nie ma także równie widocznych, jak w przypadku św. Andrzeja, śladów jego kultu.

W bliżej nieznanym czasie mógł także przebywać nad Dunajcem niejaki Just, zwany również Jodokiem. Góra św. Justa w ziemi sądeckiej została odnotowana po raz pierwszy w 1374. Swą nazwę zawdzięczała zapewne domniemanemu pustelnikowi. Około 1400 r. właściciel tego terenu ufundował mały klasztor, który objęli kanonicy regularni od pokuty, osadzeni przy kościele św. Marka w Krakowie. T. Wojciechowski za eremitów XI w. uznawał także św. Urbana z Iwkowej w ziemi sądeckiej i arcybiskupa Bogumila z Dobrowa nad Wartą ${ }^{26}$.

Do źródeł nie cieszących się zaufaniem historyków, którzy zajmują się dziejami XI stulecia, należy Żywot św. Mojżesza Węgrzyna. Nie wchodząc w szczegóły dyskusji warto tylko zauważyć, że gdy Mojżesz był więziony w Polsce, habit mnicha i tonsurę otrzymał od kogoś, kto wracał z góry Athos. Można o tym wnioskować z fragmentu, kiedy Mojżesz oznajmił dumnie swej prześladowczyni: „a ja jestem odtąd mnichem. W te bowiem dnie wracał pop pewien $\mathrm{z}$ góry świętej, i ten z polecenia Bożego przybywszy do błogosławionego, ostrzygł go i odszedł"27. Jest to tylko ułamek skomplikowanego problemu oddziaływań bizantyjskich i kijowskich na wczesny monastycyzm polski.

Źródeł inspiracji eremickich doszukiwać się należy również w XIII w. Sygnalizując tylko to zagadnienie wskażemy, że wedhug Żywotu św. Jacka napisanego w drugiej połowie XIV w., życie pustelnicze wiodła norbertanka Bronisława z klasztoru na Zwierzyńcu. Zmarła w 1259, a na podkreślenie zasługuje fakt, że jej pustelnia znajdowała się na jednym z wzgórz na Bielanach. Pierwszy to, ale ważny ślad eremityzmu na górze bielańskiej. W inne rejony wiedzie nas Żywot bł. Salomei, przełożonej klasztoru klarysek w Skale. Ona również, czerpiąc obficie z duchowości franciszkańskiej, wiodła życie pustelnicze na jednej ze skał, wznoszących się nad doliną Prądnika.

Ślady tradycji eremickich napotykamy w późnym średniowieczu w różnych zakonach, wydaje się jednak, że nie było w Polsce XIV-XV w. zbyt wielu chętnych do życia eremickiego. Wielce zasłużone dla kultury średniowiecznej klasztory kartuzów oparte były silnie na tradycjch eremickich, ale powstawały na Węgrzech i Pomorzu, a nie w Polsce. Na szczególną uwagę zasługują kartuzje spiskie (Mons Lapis Refugii i Czerwony Klasztor), gdyż ich powstanie w XIV w. wskazuje na żywotność idei pustelnictwa zapoczątkowanej przez św. Świerada na pograniczu polsko-węgierskim. Na Pomorzu wielką sławę zyskały Kartuzy koło Gdańska. Do tradycji eremickich nawiązywali sprowadzeni w 1382 r. z Węgier na

\footnotetext{
${ }^{26}$ T. W o j c i e c h ow sk i, Szkice historyczne, dz. cyt., s. 72-78.

${ }^{27} \mathrm{MPH}$ JV, s. 810
} 
Jasną Górę paulini, których patronem był św. Paweł Eremita. Nie został zrealizowany plan Jana Długosza, aby założyć klasztor kartuzów w Krakowie. Początkowo miał on powstać na Kazimierzu, ale w końcu zdecydował się, aby kartuzję założyć na wzgórzu koło wsi Bielany pod Krakowem. Do zrealizowania planów nie doszło. Obecnie góra bielańska zamieszkała jest, od 1604 r. przez kamedułów, warto jednak postawić pytanie, czy należycie doceniamy znaczenie Bielan, skoro właśnie tu w XV w, mieli osiąść kartuzi i właśnie tu w XIII w. istniała pustelnia norbertanki Bronisławy?

Ci, którzy chcieli żyć w odosobnieniu, szukać musieli eremów poza Polska. Hieronim z Pragi, który objął opactwo premonstratensów w Nowym Sączu, założone przy szpitalu św. Ducha w 1410 r., nie wytrwał w zakonie św. Norberta. Więcej, od ideałów kanonickich, cenił eremickie i dlatego opuścił Nowy Sącz i wstapił do zakonu kameđulów poza Polska. Z zakonem kartuzów związali się, dobrze znani w Krakowie, Jakub z Paradyża i Dominik z Prus.

Przytoczone przykłady oczywiście nie wyczerpują poruszanego zagadnienia. Pustelnicy na ziemiach polskich czerpali z różnorodnych źródeł. Największe znaczenie miały, co oczywiste, odmiany wypracowane w kręgu reguły św. Benedykta z Nursji. Świadczy o tym przede wszystkim, pozostający pod wpływem zwyczajów zaprowadzonych przez św. Romualda, erem Pięciu Braci Męczenników w Międzyrzeczu. Z mnichami reguły św. Benedykta może mieć związek także domniemana pustelnia pod Górą św. Benedykta pod Krakowem. W późnym średniowieczu uwage należy zwrócić na wpływy kartuzów. Postać św. Andrzeja Świerada ujawnia, jednak, również inspiracje wschodnie. $Z$ innych, niż benedyktyńska, tradycji czerpały Bronisława norbertanka i Salomea klaryska. Warto podkreślić w zakończeniu, że wszyscy znani nam $\mathrm{z}$ imienia polscy zakonnicy prowadzący życie pustelnicze, jak Benedykt, Jan, Mateusz, Izaak, Krystyn, Andrzej Świerad, ewentualnie również Benedykt, Urban, Bogumił i Just, oraz Bronisława i Salomea doczekali się kanonizacji lub przynajmniej lokalnego kultu. Świadczy to o wielkim znaczeniu tego nurtu $\mathrm{w}$ dziejach Kościoła polskiego w średniowieczu. Zwraca uwagę także spory zasięg geograficzny ich działalności. Ślady pustelników odnajdujemy ich zarówno na pograniczu zachodnim (lubuski Międzyrzecz), jak w Wielkopolsce, pod Krakowem, w dolinie Prądnika, oraz na południu kraju, w ziemi sądeckiej.

Podstawa działalnia pierwszych eremitów w Polsce była reguła św. Benedykta obostrzona przez św. Romualda. Ich erem powstał prawdopodobnie w Międzyrzeczu. Na kształtowanie się postaw pustelniczch miał także wpływ monastycyzm bizantyjski, o czym świadczy przykład sw. Andrzeja Świerada. On i jego naśladowcy działali w ziemi sądeckiej i na Słowacji. Można domniemywać istnienia w XI w. pustelników także pod Krakowem. W XIII w. ideały pustelnicze realizowano w ramach reguły premonstrateńskiej (Bł. Bronisława) i franciszkańskiej (bł. Salomea). Słabe okazało się, natomiast, oddziaływanie zakonu kartuzów. 